\title{
Beyond 3x1: Linking sending and receiving societies in the development process
}

\section{Miryam Hazán Béjar*}

Abstract: In this paper I explore the possibilities of linking and expanding sending and receiving countries' initiatives that mobilize immigrants to participate in the development process of their country of origin with two main goals: 1) to multiply their developmental impacts in sending regions; and 2) to help increase the social and political capital of immigrants and immigrant associations so as to facilitate both their role in the development process of their countries of origin, and also their integration in their host societies. In the paper I will study the Mexican $3 \times 1$ Program and Spain's co-development model and explore the ways in which programs like these could be ideally linked to be implemented in different contexts in a meaningful way for both sending and receiving societies. The paper is based on research conducted over the last nine years with Mexican immigrant associations in the United States; on interviews with Mexican government officials in Mexico and the United States; and on interviews conducted in 2008 and 2009 in Spain.

Keywords: Co-development, co-responsibility, collective remittances, cooperation for development, Mexico's 3x1 program, Hometown Associations, State federations

*Dr. Miryam Hazan is a Policy Analyst, Migration Policy Institute (MPI), Washington DC and Visiting Scholar, University of Pennsylvania. Email: hazanm@migrationpolicy.org and miryamb@sas.upenn.edu. This paper was written in the author's capacity as a consultant to the "Trade, Migration and Development" Work Package project of the NCCR - Trade Regulation program, funded by the Swiss National Research Foundation (SNF).

The NCCR Trade Regulation PAPERS are preliminary documents posted on the website (<www.nccr-trade.org $>$ ) and widely circulated to stimulate discussion and critical comment. These papers have not been formally edited. Citations should refer to a "NCCR Trade Working Paper", with appropriate reference made to the author(s).

\section{FNDWF}

FONOS NATIONAL SUISS SCHWEIZERISCHER NATIONALFONDS FONDO NAZIONALE SVIZZERO

Die Nationalen Forschungsschwerpunkte (NFS) sind ein Förderinstrument des Schweizerischen Nationalfonds Les Polles de recherche nationaux (PRN) sont un instrument d'encouragement du Fonds national suisse.

The National Centres of Competence in Research (NCCR) are a research instrument of the Swiss National Science Fondation. 


\section{Introduction}

In the last few years sending and receiving countries have been implementing programs that attempt to link diaspora or immigrant communities with the economic development of their countries of origin. The main purposes of these programs have been: 1) to help create new economic and social opportunities in sending regions as a means of reducing or containing future migration flows from those regions; and 2) to cultivate the loyalty of these communities and thus facilitate their integration in the social and economic lives of their home and/or host societies.

Mexico's 3x1 Program, in which every dollar emigrants invest in their places of origin is matched by the municipal, state, and federal governments, has been noted as particularly promising by scholars and international organizations even though its limitations as a source of long term development have also been recognized. This program has been implemented since 2001 with the help of US-based Mexican immigrant associations, although migrants need not belong to an association to participate. Parallel to initiatives like this, some receiving countries such as Spain have been implementing creative and innovative programs that attempt to promote the development of sending regions and simultaneously increase the social capital of its immigrant communities to facilitate their integration. In contrast to other destination countries such as France, in which the central government has been the key player in such attempts ( Naïr 1997, Muynck 2006), for the past few years Spain has been implementing bottom-up co-development initiatives. These clearly reproduce its strong regionalist and local traditions and also build upon international cooperation for development initiatives implemented at different levels of government after Spain joined the European Union (EU) in 1986. Through these co-development initiatives, local and regional governments have been providing financial support to local immigrant associations and NGOS that have produced projects promising to help improve socio-economic conditions in sending regions ${ }^{1}$. It is important to point out that Spain's co-development projects at the regional and local levels have also been encouraged by the central government as part of its broad agendas of immigrant integration and cooperation for development. Although the Spanish state has a long tradition of respecting the autonomy of its diverse territories, the central government also establishes national directives that promote national consistency in the policy field. In this connection, in 2004 the national government created a working group to explore the links between migration and development and to design policy directives that could guide the different activities implemented on these subjects at different levels of government. By the beginning of 2009, co-development became one of the key areas of Spain's cooperation for development policy as stated in its 2009-2012 Directive Plan of Spanish Cooperation which builds upon the co-development experiences that have

${ }^{1}$ Although co-development policies attempt to get immigrant associations directly involved in the process, many times NGOS are the ones that participate in the design and implementation projects due to the absence of strong immigrant associations. 
already been implemented as pilot experiments in different localities throughout the country.

If sender and receiver countries have a common interest in helping the sending country to develop, and in creating some level of order in the process that leads to emigration, then it makes sense to connect the stakeholders in both countries within the same framework. The main problem with the $3 \times 1$ program implemented by Mexico is that it leaves the United States, an obviously major stakeholder, out of the process; while the major problem with the Spanish model is that it does not really invite buy-in by the national and sub-national authorities in the sender countries.

In this working paper I will explore the possibilities of linking and expanding sending and receiving countries' initiatives such as the ones mentioned above with two main goals in mind: 1) to multiply their developmental impacts in sending regions as a way of increasing their capacity to reduce unwanted migration; and 2) to increase the social and political capital of immigrants and immigrant associations so as to facilitate both their role in the development process of their countries of origin, and also their integration in their host societies. In the paper I will study the Mexican and Spanish cases and explore the ways in which programs like these could be linked in different contexts in a meaningful way for both sending and receiving societies. The paper is based on research conducted over the last nine years with Mexican immigrant associations in the United States; on interviews with Mexican government officials in Mexico and the United States; and on interviews conducted in 2008 and 2009 in Spain with central, regional and local officials and with members of immigrant associations (Madrid and Basque country).

In the first section of the paper I will provide an overview of Mexico's $3 \times 1$ Program, explaining its origins, characteristics, accomplishments and limitations. In the second part I will provide an overview of Spain's co-development policies. As part of the analysis I will also delve into some of the advantages and limitations of the Spanish model as a whole. In the third section I will explore the possibilities of linking, expanding, and improving the Mexican and Spanish models. In the third section, I will present a working proposal of how an ideal model of migrant/diaspora participation in countries of origin could function if both sending and receiving countries get involved in the process. I will also suggest some of the challenges and limitations that such a model could face and some of the research agendas that can be pursued to explore its viability and limitations.

\section{Mexico's 3x1 Initiative}

In 2001, the government of President Vicente Fox created the $3 \times 1$ program with the stated goal of providing financial support from the three levels of government (municipal, state and federal) to all those initiatives proposed by migrants abroad that 
had the intention of improving the life conditions of their places of origin and "that also promoted economic and gender equality". (Soto Priante 2006 p.227) As mentioned above, every dollar migrants sent for those projects would be matched by the three levels of government, but the program as a whole would be coordinated by the Federal government through the Secretaría de Desarrollo Social (Social Development Ministry) (Sedesol) in Mexico City. Sedesol would also provide technical advice to those migrants interested in participating in the program and be accountable in guaranteeing the follow up and satisfactory completion of the projects. In addition, to ensure that the projects proposed by migrants would be relevant to the needs of the communities that would benefit from them a Committee of Validation and Attention to Migrants (COVAM), with representatives of the four parties involved (migrants, municipal, state and federal governments through Sedesol), was created.

In practice the program attempted to institutionalize and multiply the developmental effects of the activities which migrants had already been carrying out by themselves in their home towns since the late 1970s. Since then, Mexicans in the United States started to organize around their places of origin in organizations known as Home Town Associations (HTAs) to smooth their adaptation to their host country and to raise financial resources for social infrastructure projects. The later activity was voluntary although sometimes encouraged by a priest or by a municipal president. Overall, they emerged from the bottom up and showed a clear commitment by migrants to help improve the life conditions of the communities they left behind. However, they also reflected their learning process of the American experience. Compared to other developed countries, the United States has a highly individualistic society and most political action is, therefore, initiated by individuals and private associations, rather than by state institutions (Soysal 2004). This is reflected in the large number of charities and private foundations in this country, which perform a great variety of public functions. Following this same model, Mexican migrants attempted to rely not on Mexican or American state institutions - on which they could not rely, in any case -- to change the life conditions of their places of origin but on private funds they raised by themselves. The creation of the $3 \times 1$ program certainly lifted some of that weight from their shoulders, by establishing a condition of "co- responsibility" between the migrant community and the Mexican state which has clearly benefited both sides.

Mexico's 3x1 initiative has its origins in three main factors: 1) changes in Mexico's policies towards the emigrant community since the early 1990s; 2) the existence of a more settled and active Mexican expatriate community in the United States which had been interacting with municipal and state level governments since at least the mid 1980s; and 3) institutional changes in Mexico that allowed for the viability of such a program. 


\section{Changes in Mexico's policies towards its diaspora}

In 1991, the Mexican government radically transformed its policy towards its expatriate community abroad by implementing the Program for Mexican Communities Abroad (PMCA). This program attempted to engage and help organize the Mexican community in the United States, after a long period of practical neglect. Officially, the PMCA was established in response to a direct demand by Mexican-American organizations (González Gutiérrez and Schumacher 1998; Gonzáles Gutiérrez 2003). Unofficially, it was also a response to the widespread support which Cuauhtemoc Cárdenas' 1988 bid for the presidency received among Mexican communities in the United States (Smith 1998, p. 222), reflecting the government's awareness of the capacity of expatriates to mobilize towards their homeland with unpredictable consequences for the then dominant Institutional Revolutionary Party (PRI) (De la Garza 1997).

The program was to be coordinated by the 42 Mexican consulates and 23 cultural institutes in the United States. Its main tasks were to change the image of Mexican communities abroad in Mexico; to educate Mexicans abroad about Mexico, helping them establish organizations to acquire better representation in their adopted communities; and to collaborate with other institutions in the United States at the local and national levels to design and develop public policies that would help elevate the living conditions of Mexicans and people of Mexican descent (González Gutiérrez and Schumacher 1998, p. 190-191).

In this regard, the PMCA was presented as an instrument for cooperation between Mexico and the United States on long-term goals as well, which would thus require an unprecedented negotiation with the American government at the local and national levels on key topics for the Mexican community.

The Mexican state also stretched its links with the Mexican expatriates by granting Mexicans abroad access to dual nationality in 1996. This allowed them to keep their Mexican nationality while obtaining another one, and to maintain important economic rights in Mexico. In 2005, and after a long process of lobbying by the recently mobilized Mexican diaspora, the Mexican State granted emigrants the right to vote from abroad in presidential elections.

Finally, in 2002 as part of its policy towards expatriates the Mexican government created the Institute for Mexicans Abroad with the goal of addressing their needs. Although this body has only consultative capacities, it has provided an important opportunity for many Mexican leaders from different American cities to interact and exchange ideas and experiences. It also has signified for them a unique chance to acquire a unified voice. Thanks to the Council, Mexican leaders in the United States are building, with more efficiency than ever, important links and networks and have developed a better understanding of the Mexican reality and of the challenges they face for their economic, social and political integration in their host society (Hazán, 2006). 


\section{The Mexican expatriate community}

Mexico's recent policies towards its diaspora have had many consequences for both Mexico and the United States. One of their main effects was their contribution to the unprecedented mobilization of Mexicans towards their homeland as Mexican authorities (including consular officials and state governors) encouraged expatriates who were not yet organized to create new HTAs. As a result, the number of these types of organizations increased dramatically from a handful in 1990 to more than 1000 by the year 2000. Furthermore, these organizations became more sophisticated as many of them integrated into State Federations (SFs). These were umbrella organizations with a wider agenda in the homeland than the agendas pursued by HTAs. The SFs would facilitate the fundraising activities of their members and would help increase the scale of resources they could invest for social infrastructure in their places of origin. At the same time, they would facilitate the social interactions of Mexicans in their host society through the many activities they sponsored. Finally, the SFs gradually developed a political agenda first towards Mexico, and then towards the United States.

\section{The relationship with local authorities}

Prior to the creation of the PMCA, some governors, such as Genaro Borrego Estrada from Zacatecas (1986-1992), were already visiting their expatriates with the goals of tightening ties with them and guaranteeing that remittances would keep flowing into their economies.

The active role played by sub-national entities in the incorporation of expatriates is directly linked to the dismantling of the developmental state in Mexico during the 1980s and 1990s, since this process forced them to find new ways to finance the economic and social development of their regions, in a context in which the Federal Government reduced its financial participation in this endeavor. One path available for states that produced high levels of emigration was tapping their population residing abroad.

In this context, the government of Zacatecas first established a program negotiated with the SF of Los Angeles in 1992 called 2x1 in which every dollar invested by the organization would be matched by the state government and by the Federal government. Between 1993 and 1995 the federal government under the administrations of Salinas de Gortari and Ernesto Zedillo implemented the program Solidaridad Internacional or International Solidarity, which was the version oriented towards émigrés of the original Programa Nacional de Solidaridad (National Solidarity Program) or PRONASOL. This program worked along with the PCMA and institutionalized the 2x1 model negotiated with Zacatecas (Goldring 2002). A few other governments, including the government of the state of Guerrero, also took advantage of this program.

When the International Solidarity program ended the state of Zacatecas kept implementing the program $2 \times 1$ through special agreements between successive 
governors, the federal government, and the Zacatecan Federations in the United States. This program brought important investment to the state, which was the highest per capita producer of migrants in the country and also one of the poorest. However, it is also true that it also created tensions between the local political class and the emigrant community, due to the long history of corruption in Mexico and the high levels of distrust emigrants held against local authorities, and at the same time, the unwillingness of local authorities to allocate parts of their budgets already designated to other priorities to the projects suggested by HTAs. In this regard, both parties (émigrés and local authorities) had to pass through a learning process on how to interact in a more productive way.

\section{Institutional changes}

By 1997, in a context in which the Mexican government was trying to strengthen Mexico's federal pact through the decentralization of resources, the Mexican Congress granted municipal governments additional resources to implement social policies through the newly created Ramo 33 of the Fiscal Coordination Law. To use these resources, however, states and municipalities were required not only to provide public information on their use, but also to include the population in the design and evaluation of policies.

This policy represented a crucial step in the final integration of the $3 \times 1$ program. On the one hand, it granted municipal governments not only more resources, but also more capacity to decide on what to use their resources, a situation that strengthens them vis à vis other levels of government. On the other hand, it encouraged them to establish a more direct relationship with the community and by extension with migrant organizations (Soto Priante 2006). Thanks to this policy municipal governments implemented low cost but high impact social infrastructure projects that were requested by the community and financed by the money sent by their migrant families.

By 1998, the Federal government had come to participate more actively in supporting initiatives proposed by migrant organizations through Sedesol. After a petition by the government of Zacatecas this ministry supported the construction of roads financed by Zacatecan organizations abroad. However, this support was limited to very specific projects and did not include the active participation of the three levels of government (Soto Priante 2006, p.224).

When Vicente Fox arrived in power, the Federación Zacatecana del Sur de California, as the Zacatecan Federation had been called since 1997, had become so strong that the president of the leadership of the organization was able to get direct access to Fox. In February 2000, Guadalupe Gómez Lara, its president at the time, was invited to a meeting in Mexico about remittances and in a public presentation told the president that the federation would raise 5 million dollars to invest in Mexico if the federal government matched this money through a $3 \times 1$ program. The president took the 
challenge seriously and a month later he travelled to California where he officially launched the $3 \times 1$ program, which became a signature policy of his administration ${ }^{2}$.

\section{The advantages and limitations of the $3 \times 1$ Program}

Since its implementation in 2002 the $3 \times 1$ program has financed more than 6,000 projects in at least 27 states and with the involvement of over 1,000 HTAs. The average amount of money migrants have raised per year since the beginning of the program is 15 million dollars (García Zamora 2007). In the peak year 2008, they raised around 18 million dollars. Although this amount represents only a small percentage of all the remittances migrants send every year (24 billion in 2008), it certainly has represented an important contribution to the general well-being of many communities of origin, especially in poor states like Zacatecas.

Beyond the numbers, Mexican government officials and scholars have recognized that the program's main contributions have lain in its capacity to create strong links between communities of origin and communities of destination. The program allows immigrant associations to get involved and provide input in policy design, by becoming interlocutors with the three levels of government; and it has certainly promoted investment in previously marginalized communities, even if they are not always the poorest ones (García Zamora 2005).

\section{Getting the involvement of the United States}

The greatest limitation of the 3x1 Program is that it leaves the United States, an obviously major stakeholder, out of the process. Although since the implementation of the PMCA the Mexican government has attempted to increase the forms of cooperation with American authorities, bi-national collaboration on development projects is still a relatively unexplored field, despite its potential benefits not only for Mexico which would be the main recipient of this collaboration but also for the United States. This last country has an interest in Mexico's long term development not only because this may help reduce unwanted migration but also because Mexico represents a key political and economic partner. In addition, the organization of the Mexican community, historically a politically and economically marginalized one, may also facilitate its successful integration into American society. Major studies on immigrant integration have demonstrated that immigrant associations augment the social and political capital of newcomers, which in turn increases their levels of political trust and participation both through formal and informal means (Jacobs and Tillie 2004). By encouraging the formation and participation of immigrant associations in the development process of their countries of origin, host countries such as the United States can pursue the dual goal of encouraging the long term development of sending countries while facilitating the social and political integration of their immigrant populations. This has been the goal of other major immigrant recipient countries, such as France and Spain, which in

2 This information is based on an interview with Guadalupe Gómez on May 21, 2004, in Atlanta, Georgia, and a follow up of the Mexican an American press. 
recent years have been experimenting with co-development initiatives. In the next section I will describe the Spanish co-development experience. Although this model responds to a very specific historical and political context. However, understanding it can be very useful for developing an ideal scenario of how migrant participation in the economic and social development of their countries of origin could function if both sending and receiving countries get involved in the process.

\section{Spain's Co-Development experience}

From the 1850s to the 1970s Spain was a country of emigration. By the 1990s, however, this country started to attract large number of immigrants due, among other things, to its economic expansion. During this decade, most immigrants were predominantly from North Africa and Eastern Europe. In the new century, this country has also attracted large numbers of immigrants from Latin America, such as Ecuador, Colombia and, a few years later, Peru and Bolivia. Today, the foreign born population accounts for $12 \%$ of Spain's total population.

This large influx of immigrants over a short period of time has clearly created new economic and social challenges for Spain and forced it to experiment with new ways of integrating this population. In this regard, during the last two decades Spain has implemented five immigration amnesties and has designed an ambitious national integration agenda that has the goal of promoting social cohesion through policies that grant equal rights to newcomers. The directives of this agenda are defined in its 2007 Strategic Plan on Citizenship and Integration.

At the same time, the presence of a large immigrant population has also allowed the Spanish government to explore new forms of participation in the development process of poorer countries. Like other developed countries, Spain has a national cooperation for development agenda. This agenda has been institutionalized since 1986 when this country joined the European Union. As part of this policy the Spanish state committed itself to assign in the mid-term 0.7 percent of its Gross Domestic Product (GDP) every year to support the development process of the poorest countries of the world. Spanish localities and regions also assumed the same commitment. Although it took more than a decade and a long advocacy campaign to force the Spanish state seriously to implement this commitment, today the central government and many localities and regions, especially in the richest parts of the country, are attempting to achieve it. In its most recent cooperation for development plan (2009-2012) the central government has committed itself to assign 0.56 percent in 2010 and 0.7 percent in 2012 even in the current context of economic crisis. Furthermore, some places, especially where the left is relatively strong, have attempted to go even further and assign a larger amount of money - again so far, undeterred by the current economic scenario. This is the case of the city of San Sebastian. 
During the last decade, part of the money that the municipal, regional and central governments have assigned for cooperation for development has been used for co-development initiatives which have the goal of providing financial support to the development process of the sending regions and countries of their immigrant populations. In most cases, immigrants are expected to play an active role in these initiatives through their organizations, or with the help of well established NGOs that have acted as intermediaries in previous cooperation for development initiatives. This new interest at the regional and local levels in implementing co-development projects has been facilitated by the fact that regional and municipal governments are the ones that have the greatest responsibilities in the integration process of Spain's growing immigrant population, and thus are more aware of their problems and needs. Regional governments, for example, are responsible of education and health policies and thus have to attend to the specific needs of the newer populations in those areas. At the same time, when they arrive in Spain, immigrants are expected to register, regardless of their legal status, with the municipal governments of the places where they arrive. This registration is necessary for immigrants to be able to obtain any type of social service, and eventually to regularize their status if they arrived without legal documents. In this regard municipal governments represent the first echelon in the integration process of newcomers. In the next part I will present the Spanish co-development model in greater detail.

\section{The Spanish co-development model}

Co-development is still a new concept. The first description of the concept was developed in France in the 1980s but it had a different meaning from the one it has acquired today. Even though the French state was aware of the value that migrants could have in the development process of their places of origin, at the time the concept only referred to the need of cooperation between Northern and Sothern countries. The idea was that Northern and Sothern nations should work together to produce development in Southern countries. Only later, in the 1990s, was the concept associated with the need to include immigrants in the process. Despite this advance, until at least 1997 the concept was perceived by some actors in a negative way because it was also associated with the need of migrants to return to their places of origin. In this regard codevelopment was perceived as a policy of immigration control.

In 1997, after some pressure from French immigrant associations the French government commissioned a scholar of Senegalese origin, Sami Naïr, to conduct a study on the value of co-development. Naïr produced a study called Rapport de bilan et d'orientation sur la politique de codéveloppement et de liéeaux flux migratoires (Report on the balance and orientation of the policy of co-development linked to the migration flows) (Naïr 1997), in which he proposed the design of a national co-development policy based primarily on agreements between the French state and the countries of origin of its immigrant population. These agreements were expected to function in a decentralized 
way as well as to facilitate cultural and scientific exchanges and to support migrant initiatives in their places of origin (Muynck 2006).

In 1998 the French government created the post of Ministerial Delegate for Codevelopment and International Migration. The person in charge of this position was Naïr. During Naïr's tenure there were various experiments with co-development promoted by the central government and attempts at strengthening immigrant associations. This office attempted to negotiate agreements with sending countries but these countries were uninterested because the notion of co-development was still associated with the return of migrants. Trying to find new routes to implement these types of policies, in 1999 the French state created a High Council on International Cooperation in which migrants were expected to have representation. At the same time the government created a Group of Support for Micro-enterprises which had the goal of supporting migrants' investment initiatives in their places of origin. By 1999 Naïr left his position to become a European Deputy, but, nonetheless, in 2000 the French government finally signed an agreement of Co-development with Senegal. The main goals of this agreement were to facilitate the mobility of Senegalese citizens between their home and receiving states and to support the education of Senegalese in France. The agreement also attempted to support local and regional projects in Senegal and migrants' individual projects with micro-credit. Similar agreements were later signed with Mali and then with Morocco and Comoros. However, the figure of Ministerial Delegate for Co-development created in 1998 was derogated in 2002 and in its place the government created and Ambassador for Co-development position. In 2006 France passed its Immigration and Integration Law. After that, the government created a new Ministry for Immigration, Integration and National Identity and Solidarity. Through this institution France keeps experimenting with co-development policies, pursuing a more direct dialogue with the Diaspora even though co-development is still associated with return migration (Panizzon 2009).

The Spanish co-development experience, like the French, is still a work in progress. In contrast to the French model in which most of the initiative has emerged from the central state, and only afterwards regional and local governments are brought into the process, Spain has followed a clearly decentralized or bottom-up codevelopment model in which most initiatives have emerged first as pilot experiments in regions and municipalities and only afterwards the state has designed general guidelines on the subject. Co-development projects have been implemented in regions and municipalities since the year 2000 although only recently have they started to become more common. The projects implemented have followed the general guidelines produced by the central government on Cooperation for Development, which is a more general concept, but as mentioned at the beginning of the paper, the central government itself only formally adopted the notion of co-development as such in 2009. 
In its new Plan for Spanish Cooperation for Development (2009-2012) the government has attempted to avoid the French original mistake of associating codevelopment with immigration control and has emphasized its value as a development tool. In this regard, the plan suggests that the Spanish public sector should promote, along with the private sector, the immigrant organizations and the civil society of both the sending countries and Spain, spaces of dialogue, and coordination and articulation of positive actions related to migration and development. More specifically, it calls for promoting those transnational initiatives from migrants that lead to co-development projects (Plan Director de la Cooperación Española, Directive Plan of Spanish Cooperation 2009-2012 p.24). Beyond these basic points, and following the tradition of respecting the autonomy of regional and local governments, the central state leaves a lot of space for those governments to decide the types of co-development initiatives they want to implement and the emphasis they want to make with respect to what constitutes development, as long as they do not go against the Spanish agenda of cooperation for development. Furthermore, although the collaboration of all levels of government on the subject is encouraged by the central government each place, in practice, has had the choice of doing so or going alone.

The Autonomous Region of Madrid, for example, which has invested vast resources in co-development initiatives in the last few years, from 200,000 Euros in the year 2000 to more than 1,100,000 Euros by 2009, has chosen not to collaborate with the central government. Following its own agenda on international cooperation for development, in the last few years this government has financed 12 co-development projects proposed by immigrant associations, emphasizing those that focus on building governance in sending regions.

The Municipality of Madrid has also chosen to follow its own agenda, becoming a pioneer in the co-development field. Today it is the city in Spain that has invested the largest amount of resources on co-development initiatives (2 million Euros in 2008) supporting ten projects, seven of which have been carried out through NGOs and three by migrant organizations. The predominant goal of these projects is to help strengthen local institutional capacity.

Other cities such as San Sebastian and Bilbao in the Basque country where I conducted research have shown a greater interest in collaborating with the central government, but have also emphasized issues that are of particular interest to them such identity and gender ones, although they only recently started to participate in codevelopment initiatives.

For its part, the central government has signed some agreements of support for development with sending countries, especially in Africa, but is still exploring how to implicate the immigrant community in the development process and in co-development initiatives. 
As can be seen from the cases described above, co-development in Spain is still a work in progress, and thus a source of contention. What is clear, however, is that regional and local experiences are playing a very relevant role in defining all of its meanings and possibilities.

One of the major challenges of the Spanish model so far is that to really guarantee a long term impact in sending regions, there is the need to invite buy-in by the national and sub-national authorities of the sender countries where the projects are implemented. So far, the initiatives financed by Spanish regions and municipalities have been implemented by NGOs in sending places which are contacted by either the immigrant organizations or NGOs in Spain that receive the financial support. This has facilitated the possibilities of actually implementing the projects, but as an official in the region of Madrid explained, it is still highly improbable that these will leave a real legacy in the long run unless local and, ideally, regional and national governments buy in. Although some Spanish governments have signed some agreements with local governments, these are more the exception than the rule.

For co-development projects like the ones being implemented in Spain to have a clearly measurable impact on development there is the need to improve the model not only by encouraging more coordination on co-development among the three tiers of government in Spain but also by engaging in the process the governments of sending regions. In the next section I will explore this possibility.

\section{Towards a new pro-development framework that links the Mexican and Spanish Experiences}

Mexico's 3x1 initiative and the Spanish co-development projects pursued at different levels of government display similar conceptual parameters. Both the Mexican and Spanish models are guided by the assumptions that immigrants' involvement in the development process of their places of origin is crucial, that this involvement carries positive benefits for both sending and receiving societies, and that it facilitates their social integration in both societies. The Mexican model has been characterized as a form of "co-responsibility" because it encourages the active participation of all levels of government and the migrant communities in the policy process (Soto Priante 2006). However, if elevated to a more general level, this model can certainly be explained using the Spanish notion of co-development. This notion refers to "all those actions that link the transnational life of migrants with the human and translocal development processes and that involve the participation of a vast web of actors, but in which the migrants play a protagonist role (Fernández, Giménez and Puerto 2008 p.25)." 3

Both the Mexican and Spanish experiences provide interesting elements for a more general policy of co-development. Both experiences so far are fragmentary. The Mexican experience only takes into account the institutions in the country of origin and

\footnotetext{
${ }^{3}$ The definition used in the book cited is based on Cortés 2005. Another similar definition is provided by Cideal 2007 p. 31.
} 
the Mexican organizations in the United States. The Mexican model does nevertheless present an organized state action. In contrast, the Spanish model involves in its codevelopment experiences the institutions of the host country but so far with less coordinated planning than is displayed in French policy, at least at the level of the political discourse.

These experiences, however, have an element in common: the development of the sending country. What I propose here is to make a qualitative jump, at least at the conceptual level, and to create an ideal model of co-development that involves all the territorial levels of government in both the sending and receiving countries. In addition, it can involve NGOs and actors from the private sector of both host and home countries interested in participating in the process. In this model, migrant organizations and/or pro-immigrant NGOs will be the connecting element. Obviously the coordination of all these actors would require the establishment of institutional mechanisms of such as working committees or similar ones. The goal of this model would be to maximize the impact on development in the sending country by capitalizing on immigrants' privileged knowledge of the social and political realities of their countries and places of origin, and to encourage at the same time their integration into the host country. Ideally, the model would look like in the figure 1. 
FIGURE 1. MODEL OF CO-DEVELOPMENT POLICY INSTITUTIONAL FRAMEWORK

\section{SENDING COUNTRY INSTITUTIONS}

A) STATE INSTITUTIONS

(Coordinated)

- Federal/Central

- State/Regional

- Municipal/County

B) NON STATE INSTITUTIONS

(Private sector, relevant NGOs)

- Private Sector

- NGOs
RECEIVING COUNTRY INSTITUTIONS

A) STATE INSTITUTIONS

(Coordinated)

- Federal/Central

- State/Regional

- Municipal/County

B) NON STATE INSTITUTIONS

(Private Sector, relevant NGOs)

- Private Sector

- NGOs

DEVELOPMENT OF SENDING COUNTRY

- IMMI GRANTS' I NTEGRATION 
Obviously, in practice this model will be implemented only partially. For example, a country like Spain would not be able to collaborate with all the countries of origin of its immigrant population. In the first place some of these countries may lack the institutions necessary for full cooperation. However, there is the possibility of this type of collaboration with countries where there is the institutional capacity to exploit it. Spain could probably collaborate with Morocco, Ecuador and Colombia to name a few examples. The US for its part, could collaborate with Mexico, taking advantage of the bi-national collaboration channels already in place.

A possibility could be to start with pilot projects. For example, Spanish institutions (municipal, regional and central) could work in a coordinated fashion with a city or a municipality in a specific place of origin and include migrant organizations (or, in their absence, NGOs) as key actors in the design and implementation of a local development project.

The necessary elements for such experiments to work are promotion of good coordination among the institutions of both host and home countries, and exploration of innovative ways of reinforcing the social capital of migrants consistent with the goal of including them as key protagonists in the process. In this regard, how to promote this coordination among institutions in co-development initiatives, and how to increase the social capital of migrants should be elements of a new research agenda. 


\section{References}

Aparicio, Francisco Javier and Mesenguer, Covadonga. 2008. Collective Remitances and the State: The $3 \times 1$ Program in Mexican Municipalities. In www.cide.edu, October 2008.

Arango, Joaquín and Jachimowicz, Maia. 2005. Regularizing Immigrants in Spain: A New Approach. Published by Migration Policy Institute, www.migrationinformation.org

Cideal . 2007. Guía básica del codesarrollo. www.codesarrollo-cideal.org

Cortés, A. 2005. "La experiencia del codesarrollo entre Ecuador y España: una aproximación a un transnaionalismo desde el medio." In Herrera, Carrillo, and Torres A, eds. La Migración ecuatoriana: transnacionalismo, redes e identidades, Quito: FLACSO-Plan Migración Comunicación y Desarrollo: 253-277.

De la Garza, Rodolfo. 1997. “Foreign Policy Comes Home: The Domestic Consequences of the Program for Mexican Communities Living in Foreign Countries". In Bridging the border : transforming Mexico-U.S. relations. R. O. De la Garza and J. Velasco. Lanham, Md., Rowman \& Littlefield.

De Muynk, Katreen. 2006. El caso francés: la primera política official de codesarrollo. In www.codesarrollo-cideal.org. February 2006.

Fernández, Giménez, and Luis Miguel Puerto , eds. 2008. La Construcción del Codesarrollo. Madrid, Spain: Catarata.

García Zamora, Rodolfo. 2005. "Collective Remittances and the 3x1 as a Transnational Social Learning Process." Background paper presented at the seminar "Mexican Migrant Social and Civic Participation in the United States. Woodrow Wilson International Center For Scholars, Washington DC, November $4^{\text {th }}$ and $5^{\text {th }}$.

García Zamora, Rodolfo. 2007. "El Programa Tres por Uno de remesas colectivas en México. Lecciones y desafíos." In Migraciones Internacionales. Vol 4, num 1, January-June.

Goldring, Luin. 2002. "The Mexican State and Transmigrant Organizations: Negotiating the Boundaries of Membership and Participation". In Latin American Research Review 37(3): 55-100.

Gonzáles Gutiérrez, C. 2003. “Las Relaciones de México con su Diáspora: en busca de una política de Estado". In En la Frontera del Imperio. R. Fernández de Castro. México City, Ariel.

Gonzáles Gutiérrez, C. and Schumacher,M.E. 1998. “El Acercamiento de Mexico a las Comunidades Mexicanas en Estados Unidos; el Caso del PCME”. In México y Estados Unidos; las Rutas de la Cooperación. O. Pellicer and R. Fernández de Castro. México City, SRE-ITAM.

Hazan, M. 2006. Incorporating in the United States and Mexico: Mexican Immigrant Mobilization and Organization in Four American Cities. PhD Dissertation, the University of Texas at Austin.

Jacobs, D. and Tillie, J. 2004. "Introduction: Social Capital and Political Integration of Migrants." In Journal of Ethnic and Migration Studies 30(3). 
Ministerio de Asuntos Exteriores y Cooperación. 2009. Plan Director de la Cooperación Española 2009-2012. Madrid, February 2009.

Naïr, Sami. 1997. Informe de balance y orientación sobre la politica de codesarrollo vinculada a los flujos migratorios. Spanish translation by Katreen de Muynk in www.codesarrollo-cideal.org. 196-231.

Panizzon, Marion. "From Co-development to Solidarity Development: Structure and Process of Subsidizing Migrant Transmission Mechanisms in a Eurafrican Context. Paper presented at the World Bank International Conference on Diaspora for Development, July 13-14 2009, Washington DC.

Soto Priante, Sergio. 2006. "Programa 3 x 1 para migrantes". In Carlos González Gutiérrez (ed.) Relaciones Estado-Diáspora: aproximaciones desde cuatro continentes. Porrúa/ Secretaría de Relaciones Exteriores/ Instituto de los mexicanos en el Exterior/ Universidad de Zacatecas. Tomo 1: 221238.

Soysal, Yasemin Nuhoğlu. 1994. Limits of Citizenship, Migrants and Postnational Membership in Europe. Chicago: The University of Chicago Press. 


\section{List of Interviews in Spain}

- Mauricio Valiente, Deputy Secretary President of the Comisión Española de Ayuda al Refugiado (CEAR)

- Estrella Pérez Galán, Territorial Co-ordinator in Madrid of the Comisión Española de Ayuda al Refugiado (CEAR)

- María Segurado, Caritas Diocesana, Madrid

- Álvaro Zuleta, President of ACULCO (Asociación Sociocultural y de Cooperación al Desarrollo por Colombia e Iberoamérica)

- Alfonso Cortés, Secretary of ASISI (Asociación Solidaria para la Integración Sociolaboral de Inmigrantes)

- Samira, member of the Secretariat of IBN BATUTA, Asociación Sociocultural

- Carolina Mayeur Dawell, General Direction of Planning and Evaluation of Development Policies, Ministerio de Asuntos Exteriores y Cooperación, Spain

- Jaime Mira Salama, Migrations, Develoment and Humanitarian Action, General Direction of Planning and Evaluation of Development Policies, Ministerio de Asuntos Exteriores y Cooperación, Spain

- Percival Manglano, Director General of Cooperation for Development, Autonomous Community of Madrid

- Reyes Molina, Head of the Service of Cooperation for Development, City Hall of Madrid

- Ainhoa Beola, Member of the Local Council of the City of San Sebastián, responsible of the Cooperation for Development Policies (Basque County, Spain)

- Miguel Pérez, Head of the Service of Cooperation for Development, City Hall of Bilbao (Basque County, Spain)

- Carlos Regidor, Head of the Service of Immigration, City Hall of Bilbao (Basque County, Spain) 